\title{
KAWIN LARI BERSAMA (POFELEI AO) PADA MASYARAKAT ADAT BUTON (STUDI DI KELURAHAN GU TIMUR KECAMATAN LAKUDO KABUPATEN BUTON TENGAH)
}

\author{
Nilawati ${ }^{1}$ Hamuni $^{2}$, Nerlin $^{3}$ \\ Jurusan Pendidikan Pancasila dan Kewarganegaraan \\ Fakultas Keguruan dan Ilmu Pendidikan \\ Universitas Halu Oleo \\ Email: taslimnila84@gmail.com ${ }^{1}$, hamuni@gmail.com ${ }^{2}{ }_{\text {nerlin@gmail.com }}^{3}$
}

\begin{abstract}
Abstrak: Penelitian ini bertujuan untuk mengetahui faktor penyebab terjadinya kawin lari bersama (pofelei ao) dan proses penyelesaian kawin lari bersama (pofelei ao) pada masyarakat Gu Timur Kecamatan Lakudo. Adapun faktor penyebab kawin lari bersama (pofelei ao) pada masyarakat Gu Timur Kecamatan Lakudo adalah orang tua dari salah satu pihak menolak lamaran dari pihak lakilaki, menghindarkan diri dari berbagai keharusan-keharusan dalam perkawinan pinang dan menghindarkan diri dari rintangan-rintangan dari pihak orang tua atau pihak saudara. Sedangkan proses penyelesaian kawin lari bersama (pofelei ao) pada masyarakat $\mathrm{Gu}$ Timur adalah pihak laki-laki mengutus salah seorang keluarga terdekatnya untuk menyampaikan terjadinya kawin lari bersama kepada orang tua/ keluarga perempuan, keluarga pihak laki-laki dan pihak perempuan berunding untuk menyelesaikan adat pofelei ao, membayar uang ka'alanolalo kamokula hobhine, dan membicarakan pelaksanaan prosesi perkawinan.
\end{abstract}

\section{Kata kunci: Kawin lari bersama, Pofelei Ao}

\section{PENDAHULUAN}

Perkawinan menurut pasal 1 Undang-undang Nomor: 1 Tahun 1974 tentang perkawinan, adalah ikatan lahir bathin antara seorang pria dan seorang wanita sebagai suami isteri dengan tujuan membentuk keluarga (rumah tangga) yang bahagia dan kekal berdasarkan Ketuhanan Yang Maha Esa. Tujuan perkawinan yang dimaksudkan dalam Undang-Undang Nomor: 1 Tahun 1974 tentang Perkawinan dirasakan sangat ideal, karena tujuan perkawinan itu tidak hanya dilihat dari segi lahirnya saja, tetapi sekaligus terdapat adanya suatu pertautan bathin antara suami isteri yang ditujukan dalam membina kehidupan rumah tangga yang kekal dan bahagia, dengan harapan dapat dipertahankan selama hidupnya.

Indonesia yang berlatar belakang negara kepulauan, terdapat perbedaan budaya, suku, bahasa dan berbagai macam adat istiadat, yang diantaranya masingmasing memiliki tata cara pelaksanaan perkawinan yang antara daerah satu dengan daerah lainnya. Hal ini dapat dilihat dari masyarakat $\mathrm{Gu}$ Timur. Masyarakat $\mathrm{Gu}$ Timur di dalam tata cara pelaksanaan perkawinan secara normal diawali dengan tahap pesolopi, yakni tahap penjajakan yang dilakukan oleh pihak keluarga lakilaki yang bertujuan untuk mengetahui lebih dekat tentang keadaan perempuan yang akan dijadikan isteri dengan jalan pihak keluarga laki-laki mengutus seorang wali (duta) orang tua mewakili laki-laki kepada keluarga perempuan. Dengan maksud untuk mengetahui apakah anak gadisnya sudah ada laki-laki lain yang menyampaikan maksud yang sama kepada orang tua perempuan. Jika belum maka 
utusan keluarga akan menyampaikan maksudnya. Jika maksud baik dari pihak laki-laki sudah disampaikan dan diterima, maka akan berlanjut pada tahapan popohae/peminangan. Namun, apabila dalam proses memperkenalkan diri kepada masing-masing orang tua, baik itu dilakukan oleh laki-laki/perempuan sendiri maupun melalui perantaraan orang lain terjadi ketidakcocokan atau tidak direstuinya hubungan di antara mereka dengan berbagai macam alasan, maka pembicaraan tentang pelaksanaan perkawinan tidak dapat dilanjutkan. Berhubung lamarannya ditolak, maka silaki-laki menanggung rasa malu dan merasa tidak ada harga dirinya. Karena laki-laki dan perempuan tadi sudah saling mencintai, maka silaki-laki dan perempuan akan mengambil jalan pintas, yaitu dengan cara pofele $i$ ao, yaitu kawin lari bersama.

Perkawinan dengan lari bersama (wegloophuwelijk) dengan tiada peminangan atau pertunangan secara formal, ialah perkawinan lari bersama atau sama-sama melarikan diri. Maksudnya ialah untuk menghindarkan diri dari berbagai keharusan-keharusan, sebagai akibat perkawinan pinang, lebih-lebih untuk menghindarkan diri dari rintangan-rintangan dari pihak orang tua dan keluarga. (Ter Haar, 1994: 165). Terjadinya kawin lari bersama (pofelei ao) di kalangan masyaraakat Kelurahan Gu Timur antara lain disebabkan karena keluarga laki-laki sudah beberapa kali datang ke rumah perempuan untuk melamar namun keluarga perempuan menolak lamarannya.

Perkawinan seharusnya dilaksanakan berdasarkan hukum negara, syariat Islam, UU Nomor: 1 Tahun 1974 tentang Perkawinan, dan adat yang berlaku di masyarakat Buton Tengah. Namun, kenyataannya di kalangan masyarakat Gu Timur masih ditemukan pihak yang melaksanakan perkawinan dengan cara kawin lari bersama. Berdasarkan hasil observasi awal, di kalangan masyarakat Kelurahan Gu Timur Kecamatan Lakudo Kabupaten Buton Tengah masih terjadi kawin lari bersama (pofelai oa). Tahun 2014 sebanyak 2 pasang suami isteri (2 perempuan dan 2 laki-laki), 2015 dan 2016 hanya 1 pasang suami isteri (1 perempuan dan 1 laki-laki), dan 2018 sebanyak 3 pasang suami isteri (3 laki-laki dan 3 perempuan). Jadi dari tahun 2014-2018 terjadi 6 kali peristiwa kawin lari bersama. Oleh karena itu peneliti tertarik untuk meneliti tentang "Kawin Lari Bersama (pofelei ao) pada Masyarakat Adat Buton (Studi di Kelurahan Gu Timur Kecamatan Lakudo Kabupaten Buton Tengah)', Sumber: Kantor Urusan Agama Kecamatan Lakudo).

\section{Konsep Perkawinan}

Perkawinan adalah suatu peristiwa yang amat penting dalam perikehidupan masyarakat kita, sebab masalah perkawinan itu tidak hanya menyangkut wanita dan pria bakal mempelai saja tetapi juga kedua belah pihak dari orang tua, saudarasaudaranya bahkan keluarga-keluarga mereka masing-masing. Menurut Ter Haar, Bzn. ( 1994: 159) perkawinan adalah suatu usaha atau peristiwa hukum yang menyebabkan terus berlangsungnya golongan dengan tertibnya dan merupakan suatu syarat yang menyebabkan terlahirnya angkatan baru yang meneruskan golongan itu tersebut.

Menurut Wirjono Prodjodikoro (dalam Sudarmawan, 2009: 22) perkawinan adalah suatu hidup bersama dari seorang laki-laki dan seorang perempuan yang memenuhi syarat-syarat yang termasuk dalam peraturan tersebut". Menurut R. Subekti (dalam Sudarmawan, 2009: 23) perkawinan adalah pertalian yang sah antara seorang laki-laki dan seorang perempuan untuk waktu yang lama. 


\section{Bentuk-Bentuk Perkawinan Dalam Hukum Adat}

Menurut Ter Haar, Bzn (1994:160-169) mengemukakakn bahwa bentukbentuk perkawinan yaitu:

1. Perkawinan pinang (aanzoekhuwelijk): pihak kesatu (kebanyakan pihak pemuda) dengan menghidangkan sirih sebagai tanda lamaran, yang apabila disetujui oleh pihak perempuan dan setelah tercapai persetujuan antara kedua belah pihak diikuti oleh "pertunangan".

2. Perkawinan lari bersama (wegloophuwelijk): bakal si jodoh lari bersama dengan tiada peminangan atau pertunangan secara formal, ialah perkawinan sslari bersama atau sama-sama melarikan diri (wegloophuwelijk of vluchthuwelijk). Maksudnya ialah untuk menghindarkan diri dari berbagai keharusan, sebagai akibat perkawinan pinang, lebih-lebih untuk menghindarkan diri dari rintanganrintangan dari pihak orang tua dan sanak saudara.

3. Perkawinan bawa lari (schaakhuwelijk) ialah kadang-kadang: Lari dengan seorang perempuan yang sudah ditunangkan atau dikawinkan dengan orang lain, terkadang membawa lari perempuan dengan paksaan.

4. Perkawinan jujur, (bruidschat huwelijk), penyerahan uang dan barang-barang dari pihak suami kepada kerabatnya si isteri dengan maksud memasukkan si isteri ke dalam golongan si suami, sedemikian rupa sehingga anak-anaknya yang akan lahir sebagai angkatan mudanya bagian clan nya si suami untuk meneruskan clan nya.

5. Perkawinan mengabdi (dienhuwelijk), suatu perkawinan di mana suami dan isteri sudah memulai hidup berkumpul, tapi si suami bekerja mengabdi kerabat mertuanya sampai jujurnya terbayar lunas.

6. Perkawinan bertukar (ruilhuwekijk): atau di lain pihak suatu perkawinan dalam suatu susunan, di mana diperbolehkan mengadakan hubungan-hubungan perkawinan bertimbal balik, di mana seakan-akan pembayaran jujur yang harus dipenuhi bertimbal-balik diperhitungkan satu dengan yang lain sehingga menjadi hapus kedua-duanya.

7. Perkawinan mengganti dan perkawinan meneruskan (vervang en vervolghuwelijk): bila seorang lelaki dari sesama clan meneruskan perkawinannya saudaranya laki-laki yang mati, atau bila seorang perempuan mengganti perkawinannya saudaranya perempuan yang mati, kesemuanya tanpa pembayaran jujur baru.

\section{Konsep Kawin Lari}

Kawin lari merupakan lari dengan seorang perempuan yang sudah ditunangkan atau dikawinkan dengan orang lain, terkadang membawa lari perempuan dengan paksa, (Ter Haar, 1994: 165-166).

Menurut Setiady (2013: 246-247) daerah yang mengenal kawin lari, yaitu:

a. Lampung

Biasanya bakal suami serta bakal isteri bersama-sama melarikan diri dengan meninggalkan surat atau sesuatu barang dan bahkan kadang-kadang sejumlah uang di rumah bakal isteri. Surat atau barang yang ditinggalkan disebut peninggalan dan kemudian mereka yang melarikan diri tersebut mencari perlindungan kepada salah satu keluarga atau kepala persekutuan. Perlarian bersama ini selaku tindakan atau merupakan perlakuan pendahuluan dari 
perkawinan mereka, oleh karenanya perkawinan ini dinamakan Kawin Lari atau Wegloop Huwelijk (Vlucht Huwelijk- Ter Haar).

b. Kalimantan

Bakal suami dan bakal isteri yang sudah terikat pada seseorang laki-laki lain oleh pertunangan bahkan kadang-kadang oleh ikatan perkawinan bersamasama melarikan diri. Dalam perkawinan yang didahului oleh pelarian demikian, mempelai laki-laki wajib memberi ganti rugi kepada pihak yang terhina (lakilaki tunangan atau suami dari isteri yang melarikan diri) serta wajib juga membayar pengeluaran biaya perkawinan biasa lainnya.

c. Bali dan Lampung

Bakal suami melarikan bakal isteri dengan paksa artinya bertentangan dengan kehendak wanita yang bersangkutan (semacam penculikan). Ini disebut kawin rangkat (Schaak Huwelijk-Ter-Haar). Dalam perkawinan semacam ini mempelai laki-laki wajib memberi ganti rugi juga kepada pihak yang terhina, di samping itu harus pula membayar pengeluaran-pengeluaran perkawinan biasa lainnya. Pembayaran ini seringkali lebih tinggi dari biaya perkawinan biasa.

d. Sulawesi Selatan

Tiap perkawinan antara pemuda dan pemudi yang didahului oleh pelarian mereka bersama disebut sebagai kawin rangkat sebab peristiwa ini senantiasa menimbulkan tantangan-tantangan dari pihak keluarga pemudi bakal isteri. Hukum adat memberi hak kepada keluarga pihak pemudi untuk membunuh sipemuda yang sungguh-sungguh melakukan penculikan.

\section{Konsep Perkawinan Lari Bersama (vlucht huwelijk) (wegloop huwelijk)}

Perkawinan dengan cara lari bersama ini dilakukan untuk menghindarkan diri dari berbagai keharusan sebagai akibat perkawinan dengan cara pelamaran atau peminangan, atau juga untuk menghindarkan diri dari rintangan-rintangan pihak orang tua dan sanak saudara pihak perempuan.

Menurut Setiady (2013: 249), cara melakukan perkawinan lari bersama di beberapa daerah, yaitu:

a. Masyarakat Lampung beradat pepaduan

Setidak-tidaknya gadis yang pergi belarian harus meninggalkan tanda kepergiannya berupa surat tengepik dan sejumlah uang tengepik, pergi menuju ke tempat kediaman bujang atau ketempat Punyimbang (kepala adat), kemudian pihak bujang mengadakan pertemuan kerabat dan mengirim utusan untuk menyampaikan permintaan maaf dan memohon penyelasaian yang baik dari pihak kerabat gadis lalu diadakan perundingan kedua belah pihak.

b. Daerah Lampung beradat pesisir

Setelah gadis diketahui pergi belarian maka pihak kerabat mengusut jejak kemana gadis itu lari atau pergi. Kedatangan pencari jejak dari pihak gadis itu harus diberi kesempatan untuk bertanya kepada anak gadis mereka apakah atas kemauan sendiri atau dipaksa.

c. Daerah Bugis-Makassar

Disebut silariang dimana pihak kerabat yang mengetahui gadis mereka pergi berlari atau mengejar (tomasiri) dimana apabila belum sampai ditangan kepala adat maka sibujang yang melarikan dapat dibunuh. 


\section{d. Lingkungan Daya Ngaju (Kalimantan)}

Berlaku adat dimana sigadis mendatangi rumah sibujang untuk memaksakan perkawinan atau sebaliknya sibujang mendatangi rumah sigadis dengan membawa barang-barang pemberian kemudian meminta untuk dikawinkan, jika pihak gadis menolak maka pihak gadis harus mengganti senilai barang pemberiannya, dan dapat pula terjadi sibujang ketika berada di rumah sigadis dikurung sampai pagi lalu sigadis memaksa orang tuanya untuk dikawinkan dengan sibujang tersebut.

e. Toraja (Sulawesi)

Pada masyarakat osing berlaku adat ngeleboni (yaitu pemuda mendatangi rumah sigadis meminta untuk dikawinkan) atau sebaliknya ngunggah-ngunggahi (Nyungkemi) dimana sigadis datang kerumah sibujang untuk meminta dikawinkan. Maka kemudian pihak keluarga yang didatangi akan mengirim colok kepada pihak keluarga yang bersangkutan untuk menyelesaikan perkawinan mereka.

Menurut Hadikusuma (2014: 182) perkawinan lari bersama adalah perbuatan belarian untuk melaksanakan perkawinan atas persetujuan si gadis (wanita). Cara melakukan belarian tersebut ialah bujang dan gadis sepakat melakukan kawin lari pada waktu yang sudah ditentukan melakukan lari bersama, atau si gadis secara diam-diam diambil kerabat pihak bujang dari tempat kediamannya, atau si gadis datang sendiri ke tempat kediaman pihak bujang.

Menurut Sudiyat (1981: 114) kawin lari bersama adalah jenis perkawinan yang terjadi dengan larinya calon suami-isteri tanpa peminangan formal dengan maksud menghindarkan diri dari bermacam ragam keharusan sebagai konsekuensi kawin pinang, lebih-lebih dari campur tangan dari rintangan-rintangan pihak orang tua serta kelompok kerabat.

\section{Faktor Penyebab Kawin Lari Bersama}

Hadikusuma (2007: 43) menjelaskan bahwa penyebab kawin lari bersama bujang dan gadis, antara lain dikarenakan:

1. Persetujuan bujang gadis untuk melakukan perkawinan ditolak orang tua atau lamaran dari salah satu pihak ditolak yang lain.

2. Uang jujur (mas kawin) yang diminta kerabat wanita terlalu tinggi.

3. Si wanita selama berpacaran sudah hamil.

Menurut Ter Haar (1994: 165) beberapa faktor yang dapat menjadi penyebab terjadinya kawin lari bersama yaitu:

1. Untuk menghindarkan diri dari berbagai keharusan-keharusan sebagai akibat perkawinan pinang.

2. Lebih-lebih untuk menghindarkan diri dari rintangan-rintangan dari pihak orang tua dan sanak saudara.

Soekanto (1983: 247) menjelaskan penyebab terjadinya kawin lari bersama bahwa: perkawinan dengan lari bersama dilakukan untuk menghindarkan diri dari berbagai keharusan sebagai akibat perkawinan dengan cara pelamaran atau pertunangan atau juga untuk menghindarkan diri dari rintangan-rintangan dari pihak orang tua dan sanak saudara pihak perempuan. 


\section{Penyelesaian Kawin Lari Bersama}

Menurut Hadikusuma (2014: 183) menjelaskan proses penyelesaian kawin lari bersama adalah: gadis yang pergi berlarian harus meninggalkan tanda kepergiannya berupa surat dan sejumlah uang, pergi menuju ke tempat kediaman (kepala adat atau bujang), kemudian pihak bujang mengadakan pertemuan kerabat dan mengirim utusan kepada keluarga si gadis untuk menyampaikan permintaan maaf dan memohon penyelesaian yang baik dari pihak kerabat wanita, lalu diadakan perundingan kedua pihak.

Menurut Soekanto dan Soleman B. Taneko (1990: 251) mengemukakan bahwa: penyelesaian perkawinan dengan cara lari bersama ini dimulai dengan cara pihak laki-laki datang untuk menyatakan bahwa telah melakukan perbuatan salah dan maaf kepada keluarga si gadis, dan tempat memohon maaf ini dilakukan pada keluarga pihak gadis yang mempunyai wewenang sebagai penyeimbang.

Menurut Erens, E (2011: 97) proses penyelesaian kawin lari bersama adalah bahwa:

1. Pihak laki-laki dan perempuan yang melakukan kawin lari bersama melaporkan diri mereka dan bersembunyi di rumah pemangku adat/agama, atau kepala salah seorang tokoh masyarakat.

2. Tokoh adat atau agama atau tokoh masyarakat tersebut berinisiatif untuk memberitahukan hal ini kepada keluarga laki-laki untuk memberitahukan kejadian, sedangkan untuk keluarga perempuan dikirim utusan khusus.

3. Apabila keluarga perempuan dapat menerima kejadian ini dengan baik maka akan di atur pelaksanaan acara adat pembayaran denda kepada pihak laki-laki sebagai pertanggung jawaban atas perbuatan yang dilakukannya membawa lari perempuan.

\section{METODE PENELITIAN}

\section{Lokasi Penelitian}

Penelitian ini dilaksanakan di Kelurahan Gu Timur, Kecamatan Lakudo, Kabupaten Buton Tengah. Alasan pemilihan lokasi tersebut karena pada masyarakat $\mathrm{Gu}$ Timur masih ditemukan pihak yang melaksanakan kawin lari bersama.

\section{Jenis Penelitian}

Jenis penelitian ini adalah penelitian deskriptif dengan pendekatan kualitatif di mana peneliti memberikan gambaran dasar dan informasi yang nyata tentang kawin lari bersama (pofelei ao) serta faktor-faktor penyebab terjadinya kawin lari bersama dan proses penyelesaiannya pada masyarakat adat Buton di Kelurahan Gu Timur Kecamatan Lakudo Kabupaten Buton Tengah.

\section{Responden dan Informan Penelitian}

Responden dalam penelitian ini adalah 4 pasangan suami-istri ( 8 orang) di Kelurahan $\mathrm{Gu}$ Timur yang melaksanakan kawin lari bersama (pofelei ao), terdiri dari 4 orang laki-laki sebagai suami dan 4 orang perempuan sebagai istri. Informan dalam peneltian ini berjumlah 4 orang terdiri dari 1 orang tokoh adat, 1 orang tokoh agama Islam, 1 orang tokoh masyarakat, Lurah Gu Timur.

\section{Teknik Pengumpulan Data}

Untuk memperoleh data dalam penelitian ini menggunakan prosedur pengumpulan data melalui penelitian lapangan (field research) yaitu pengumpulan data empiris dilapangan dengan teknik: 
1. Wawancara, yaitu melakukan tanya jawab secara langsung dengan responden dan informan, untuk mendapatkan data tentang penyebab terjadinya kawin lari bersama di Kelurahan Gu Timur Kecamatan Lakudo Kabupaten Buton Tengah dan proses penyelesaiannya berdasarkan adat Buton.

2. Dokumenter, yaitu data dokumen yang berhubungan dengan penelitian ini yang berupa dokumentasi tokoh adat, tokoh masyarakat, tokoh agama Islam dan data yang memberi informasi tentang yang melaksanakan kawin lari bersama di Kelurahan Gu Timur Kecamatan Lakudo Kabupaten Buton Tengah.

\section{Teknik Analisis Data}

Teknik analisis data yang digunakan dalam penelitian ini mengacu pada pendapat Miles and Huberman (dalam Sugiyono: 369-375), meliputi tiga komponen yaitu:

1. Reduksi data (Data reduction)

Merupakan bagian dari analisis data yang merangkum, memilih hal-hal yang pokok, memfokuskan pada hal-hal yang penting, dicari tema, dan polanya.

2. Penyajian data (Data display)

Dalam penelitian kualitatif, penyajian data bisa dilakukan dalam bentuk uraian singkat, bagan, hubungan antar kategori, flowchart dan sejenisnya. Dalam hal ini Miles and Huberman (dalam Sugyono, 2015: 373) menyatakan yang paling sering digunakan untuk menyajikan data dalam penelitian kualitatif adalah dengan teks yang bersifat naratif.

3. Penarikan kesimpulan dan verifikasi (conclusion drawing/verification)

Kesimpulan awal yang dikemukakan masih bersifat sementara dan akan berubah bila tidak ditemukan bukti-bukti yang kuat yang mendukung pada tahap pengumpulan data berikutnya. Tetapi apabila kesimpulan yang dikemukakan pada tahap awal, didukung oleh bukti-bukti yang valid dan konsisten saat peneliti kembali ke lapangan mengumpulkan data, maka kesimpulan yang dikemukakan merupakan kesimpulan yang kredibel. Kesimpulan dapat diwujudkan dalam tema.

\section{HASIL DAN PEMBAHASAN}

Penyebab Kawin Lari Bersama (Pofelei Ao) di Gu Timur Kecamatan Lakudo

Kawin lari bersama/pofelei ao pada masyarakat Buton khususnya di Kelurahan Gu Timur Kecamatan Lakudo masih terus terjadi sampai saat ini. Menurut salah seorang informan selaku ketua lembaga adat di Kelurahan $\mathrm{Gu}$ Timur Kecamatan Lakudo terdapat beberapa faktor kasus kawin lari bersama.

Berdasarkan penelitian ditemukan ada kesamaan dan perbedaan kasus dari faktor penyebab kawin lari bersama. Ini dapat diketahui dengan hasil wawancara bersama beberapa responden.

1. Orang tua dari salah satu pihak menolak lamaran dari pihak laki-laki.

2. Menghindarkan diri dari berbagai keharusan-keharusan dalam perkawinan pinang.

3. Menghindarkan diri dari rintangan-rintangan dari pihak orang tua atau pihak saudara. 


\section{Proses Penyelesaian Kawin Lari Bersama (Pofelei Ao) Menurut Adat Buton di Kelurahan Gu Timur Kecamatan Lakudo}

Penyelesaian kawin lari bersama pada akhirnya dilaksanakan sesuai dengan ketentuan dan tahapan perkawinan normal. Namun terlebih dahulu diawali beberapa ketentuan adat yang harus diselesaikan oleh pihak laki-laki sebelum melanjutkan pada proses penyelesaian perkawinan normal. Ketentuan-ketentuan adat yang harus diselesaikan oleh pihak laki-laki sebagai akibat tindakan kawin lari bersama yaitu:

1. Pihak laki-laki mengutus salah seorang keluarga terdekatnya untuk menyampaikan terjadinya kawin lari bersama kepada orang tua/ keluarga perempuan

2. Keluarga pihak laki-laki dan pihak perempuan berunding untuk menyelesaikan adat pofelei ao

3. Membayar uang ka'alanolalo kamokula hobhine

4. Membicarakan pelaksanaan prosesi perkawinan

\section{PENUTUP}

\section{Kesimpulan}

Berdasarkan pada hasil penelitian dan pembahasan, maka penulis dapat mengemukakan beberapa kesimpulan mengenai penyebab kawin lari bersama (pofelei ao) dan penyelesaiannya menurut adat Buton khususnya di Kelurahan $\mathrm{Gu}$ Timur Kecamatan Lakudo Kabupaten Buton Tengah sebagai berikut:

1. Penyebab kawin lari bersama (pofelei ao) pada masyarakat $\mathrm{Gu}$ Timur Kecamatan Lakudo yaitu orang tua dari salah satu pihak menolak lamaran dari pihak laki-laki, menghindarkan diri dari berbagai keharusan-keharusan dalam perkawinan pinang dan menghindarkan diri dari rintangan-rintangan dari pihak orang tua atau pihak saudara.

2. Penyelesaian kawin lari bersama (pofelei ao) yang terjadi di Kelurahan $\mathrm{Gu}$ Timur diatur berdasarkan ketentuan adat yang berlaku pada masyarakat Buton khususnya di Kelurahan Gu Timur Kecamatan Lakudo yaitu pihak laki-laki mengutus salah seorang keluarga terdekatnya untuk menyampaikan terjadinya kawin lari bersama kepada orang tua/ keluarga perempuan, keluarga pihak lakilaki dan pihak perempuan berunding untuk menyelesaikan adat pofelei ao, membayar uang ka'alanolalo kamokula hobhine, dan membicarakan pelaksanaan prosesi perkawinan.

\section{Saran}

Adapun yang dapat menjadi saran dalam penelitian ini adalah:

1. Kepada orang tua diharapkan dapat memberi restu kepada anaknya, menentukan mahar sesuai kemampuan pihak laki-laki agar kasus kawin lari bersama tidak akan pernah terjadi.

2. Peran serta masyarakat Kelurahan Gu Timur sangat diharapkan dalam menjaga dan mengembangkan nilai-nilai adat yang berlaku agar tetap dilestarikan dalam proses penyelesaian kawin lari bersama (pofelei ao).

\section{DAFTAR PUSTAKA}

Erens E. 2011. Hukum Adat Orang Tolaki. Yogyakarta: Teras. 
Hadikusuma, Hilman. 2014. Pengantar Ilmu Hukum Adat Indonesia Edisi Revisi. Bandung: CV. Mandar Maju.

Hadikusuma, Hilman. 2007. Hukum Perkawinan Indonesia Menurut Perundangan, Hukum Adat, Hukum Agama. Bandung: Alumni.

Setiady, Tolib. 2013. Intisari Hukum Adat Indonesia (Dalam Kajian Kepustakaan). Bandung: Alfabeta.

Soekanto, Soerjono. 1983. Peranan dan Kedudukan Hukum Adat Indonesia. Jakarta: Kurnia Esa.

Soekanto, Soerjono dan Soleman B. Taneko. 1990. Sosiologi Suatu Pengantar. Jakarta: Kurnia Esa.

Sudarmawan. 2009. Pelaksanaan Kawin Lari Sebagai Alternatif Untuk Menerobos Ketidaksetujuan Orang Tua Setelah Berlakunya Undang-Undang Nomor: 1 Tahun 1974 Tentang Perkawinan. Semarang: Tesis di publikasikan.

Sudiyat, Iman. 1981. Sketsa Asas Hukum Adat. Yogyakarta: Liberty.

Ter Haar, Barend Bzn. 1994. Asas-Asas dan Susunan Hukum Adat Terjemahan K. Ng. Soebakti Poesponoto. Jakarta: PT. Pradnya Paramita. 